FROM VICTORY TO PEACE 


\section{A VOLUME IN THE NIU SERIES IN \\ SLAVIC, EAST EUROPEAN, AND EURASIAN STUDIES \\ Edited by Christine D. Worobec}

For a list of books in the series, visit our website at cornellpress.cornell.edu. 


\title{
From Victory to Peace
}

Russian Diplomacy after Napoleon

\author{
20
}

Elise Kimerling Wirtschafter

NORTHERN ILLINOIS UNIVERSITY PRESS

AN IMPRINT OF CORNELL UNIVERSITY PRESS

ITHACA AND LONDON 


\section{Copyright (C) 202I by Cornell University}

The text of this book is licensed under a Creative Commons AttributionNonCommercial-NoDerivatives 4.0 International License: https://creativecommons.org/licenses/by-nc-nd/4.o/.

To use this book, or parts of this book, in any way not covered by the license, please contact Cornell University Press, Sage House, 512 East State Street, Ithaca, New York I4850. Visit our website at cornellpress.cornell.edu.

First published 202I by Cornell University Press

Library of Congress Cataloging-in-Publication Data

Names: Wirtschafter, Elise Kimerling, author.

Title: From victory to peace: Russian diplomacy after Napoleon / by Elise Kimerling Wirtschafter.

Description: Ithaca [New York]: Northern Illinois University Press, an imprint of Cornell University Press, 202I. | Series: NIU series in Slavic, East European, and Eurasian studies | Includes bibliographical references and index. |

Identifiers: LCCN 2020037692 (print) | LCCN 2020037693 (ebook) | ISBN 9781501756016 (paperback) | ISBN 9781501756498 (pdf) | ISBN 9781501756030 (epub)

Subjects: LCSH: Russia-Foreign relations-180I-1825. | Russia-HistoryAlexander I, I80I-I825. | Europe-Foreign relations-I8I5-I87I. | Russia-Foreign relations-Europe. | Europe-Foreign relations-Russia.

Classification: LCC DKI97.W57 2021 (print) | LCC DKI97 (ebook) | DDC $327.47009 / 034-\mathrm{dc} 23$

LC record available at https://lccn.loc.gov/2020037692

LC ebook record available at https://lccn.loc.gov/2020037693

Cover image adapted by Valerie Wirtschafter. 


\section{$\mathrm{S} \mid \mathrm{H}$ The Sustainable History Monograph Pilot \\ $\mathrm{M} / \mathrm{P}$ Opening up the Past, Publishing for the Future}

This book is published as part of the Sustainable History Monograph Pilot. With the generous support of the Andrew W. Mellon Foundation, the Pilot uses cutting-edge publishing technology to produce open access digital editions of high-quality, peer-reviewed monographs from leading university presses. Free digital editions can be downloaded from: Books at JSTOR, EBSCO, Hathi Trust, Internet Archive, OAPEN, Project MUSE, and many other open repositories.

While the digital edition is free to download, read, and share, the book is under copyright and covered by the following Creative Commons License: CC BY-NC-ND 4.o. Please consult www.creativecommons.org if you have questions about your rights to reuse the material in this book.

When you cite the book, please include the following URL for its Digital Object Identifier (DOI): https://doi.org/I0.7298/dm6r-4f9I

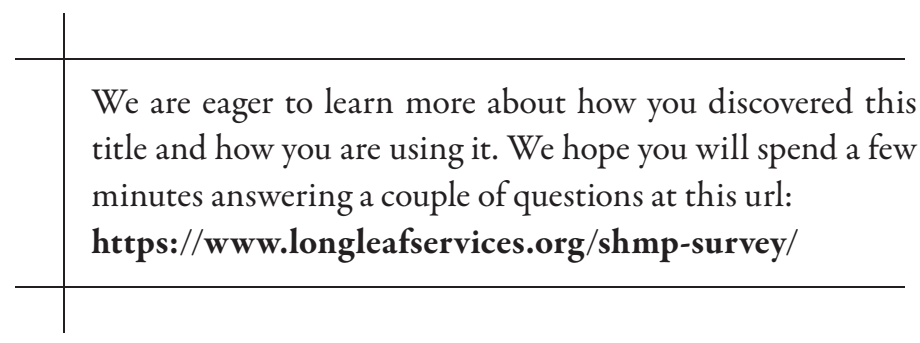

More information about the Sustainable History Monograph Pilot can be found at https://www.longleafservices.org. 

To my soulshine, Landon and Papy

20 
